\title{
Perspectives on evidence-based knowledge for teachers: acquisition, mobilisation and utilisation.
}

\author{
Linda La Velle and Maria Assunção Flores ${ }^{\mathrm{b}}$ \\ aInstitute of Education, University of Plymouth, UK; 'bnstitute of Education, University of Minho, Braga, \\ Portugal
}

\begin{abstract}
This introductory paper reviews the literature on the use of evidencebased knowledge (EBK) in the initial and continuing professional development of teachers and also in their everyday practice. It will set the scene for the theme of the SI and critically discuss general current issues about the generation of educational research evidence, how teachers may, or may not, acquire this and, drawing on and updating the outcomes of the previous JET SI (41 (5), 2014), some of the implications of translational research and knowledge mobilisation.
\end{abstract}

\section{KEYWORDS}

Teachers' knowledge; knowledge mobilisation; information and communications technologies

\section{Teachers' knowledge}

Teaching is an intellectual, critical profession (Duggan and la Velle 2018). The corpus of academic and professional knowledge for a teacher is vast and dynamic and engagement with research developments in an effective teacher's subject and practice is a career-long requirement and commitment. Because teachers are professionals, their education requires more than just teaching and management skills, (Zeichner 2014). They do need to master the technical dimension of teaching but their profession involves more than that. Issues such as reflection, emotions, beliefs, dispositions, agency, professional values, etc. are key in developing as a teacher along with robust knowledge. This is even more relevant at times when teaching is marked by growing tensions and paradoxes with implications for teacher education such as preparing for professional autonomy in a world of externally imposed educational policy. Additionally, the pressure to achieve immediate results and successes in external measures, such as examinations and league tables, versus the need to prepare students in an era of migration and growing multiculturalism in school contexts (Ben-Peretz and Flores 2018), is set against a backdrop of the requirement for $21^{\text {st }}$ century skills. As workers with knowledge who play a key role in promoting the social and cultural dimension of children and their families (Flores and Ferreira 2016), teachers need a set of knowledge, competencies, dispositions, attitudes, etc. including the ethical, social, cultural, political dimension of teaching and teacher education (Flores 2016).

As such, a solid base of knowledge is required of a teacher whose work goes beyond the mere implementation of top-down initiatives or the transmission of externally predefined knowledge and skills. They make use of their discretionary judgment in 
teaching. Not only do they make decisions that might be determined by contextual pressures and time demands that influence their professional judgment and expertise, they also might make use of their professional space even in contexts marked by growing standardisation (Oolbekkink-Marchand et al. 2017).

Ben-Peretz and Flores (2018, p. 210) argue that 'a global view of teacher education programmes might serve the creation of some unity in processes of teaching and learning, on one hand, while expanding the world of potential diversity and learning about others, on the other hand'. They argue for a common base knowledge as those components of the teaching profession that are shared by teachers in every teaching situation such as the content to be taught, and the act of the teacher and the learning activities of the students.

Lee Shulman's seminal work through the 1980s on teachers' knowledge bases in the context of teacher education is well documented, for example by Bennett and Carré (1993), and has been debated and refined over the intervening thirty years (see for example Sockett 1987; Duncan 1998; Henderson 1988; Hill, Loewenberg Ball, and Schilling 2008). According to Shulman (1987), the main categories of knowledge that the effective teacher must gain and maintain are:

- subject knowledge, both syntactic and substantive;

- pedagogic knowledge, i.e. general principles of teaching, such as lesson planning, class management, etc;

- pedagogic content knowledge, i.e. that knowledge about how to teach a particular concept or topic;

- curriculum knowledge;

- knowledge of learners;

- knowledge and understanding of educational contexts, local, regional and national.

In relation to these knowledge bases, Shulman (1987) proposed a cycle of pedagogic reasoning and action, exemplified for teaching science through ICT by Baggott la Velle, Watson, and Nichol (2000), see Figure 1.

UK teachers have to master over one thousand professional concepts and in Portugal they need to develop a set of competencies related to teaching and learning, to professional development activities, to involvement in the school activities and liaison with the community and to the ethical, social and professional dimension of teaching. Many of these have, over the course of many years, been enshrined in professional standards and codes of practice of various countries, for example in the UK teachers' standards, (UK Government 2011); in Portugal the national framework for teacher education (Decree-Law No 79/2014, 14 May) (Decree-Law 2014) Portugal and in the USA (Ben-Peretz and Flores 2018; CAEP, 2018). Each of the competencies listed in these many professional blueprints are either actually or potentially grounded in research-based evidence. By its very definition, new knowledge made public, research is constantly being made available. However, within the field of Education as an academic discipline, there is a disconnect between the generators of research and practitioners, be they classroom teachers, student teachers or teacher educators (Ketter and Stoffel 2008; Pine 2013). There is a strong perception that much educational research is irrelevant to practice (see for example Milburn 2005; Smeyers 2006). If the knowledge bases for teachers are to move from a craft-based notion of professionalism it is crucial that research evidence, pertinent to the practice of teaching, is made available to educators at all levels. 


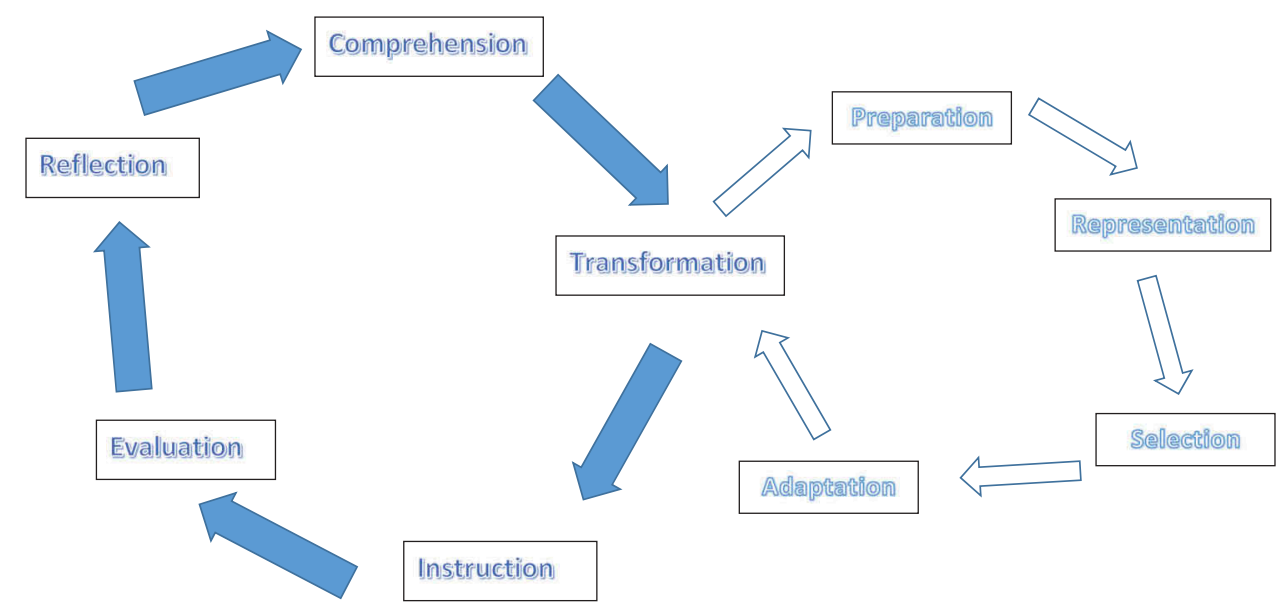

Figure 1. Shulman's cycle of pedagogical reasoning and action. the cycle begins and ends with an act of comprehension on behalf of the teacher. Given an understanding of the ideas to be taught, and the curricular purposes to be achieved, they then transform these into pedagogically potent practice. This involves them in another cycle of action: preparation (critical scrutiny and choice of teaching materials, based on intimate knowledge of them) $\Rightarrow$ representation (consideration of how the key ideas can best be represented to the pupils) $\Rightarrow$ instructional selection (choice of class management and teaching strategies) $\Rightarrow$ adaptation (methods of differentiation). Following this invocation of their pedagogic content knowledge, teachers then instruct (carry out the lesson), during which time they evaluate the teaching and learning processes (asking themselves, 'how do I know what the pupils know?'), after which they reflect on the lesson (asking themselves, 'what went well; what went not so well?' and, critically, 'why?'). (After la Velle, Watson, and Nichol (2000)).

Each one of the stages of the cycle of pedagogic reasoning and action, (Figure 1) can be informed by research. For example, a teacher can learn about developments in his/ her own subject or in the pedagogy of the discipline. Transforming that new knowledge into pedagogic content knowledge can also be enhanced by a teacher's engagement with pedagogic research, either by reading articles from educational journals or synopses of research. Elements of the transformation cycle can also be informed by research by critical action: preparation (e.g. informed choice of new resources); representation (e.g. evidence based approaches to modelling a concept); instructional selection (e.g. evidence-based classroom methodology); adaptation (e.g. new ways of differentiating a topic to enable access to the curriculum for all pupils).

How knowledge is acquired and utilised by teachers therefore poses an urgent challenge for teacher education, both initial and continuing. We propose here a model for the acquisition, mobilisation and utilisation of knowledge for teachers that is grounded in evidence based research.

\section{Knowledge acquisition}

Where do teachers and student teachers go to acquire knowledge? Time is a teacher's rarest commodity and appraising themselves of new developments either in their subject or in the pedagogy of it can be problematic. As Levin (2013) argues, having access to research is not enough. He states that 
Because education is a practice with many aspects, a teacher would need to be familiar with research in a very wide range of fields, from motivation to curriculum to pedagogy to diversity and special needs to parent and family relations to assessment and measurement and so on (p. 18).

However, the relevance of and need to foster a more research-based teaching profession remains important. The challenge is how to connect research and teaching in a more consistent and adequate way. Information written for different audiences can provide a useful entry point and it is important that researchers make their work available to the widest readership to ensure that it has the maximum impact. This is illustrated in Figure 2, which describes different types of writing for different audiences. Acknowledging the tenuous nature of the links between research and teaching, Rey and Gaussel (2016) advocate that authors consider teachers and school leaders as potential users prior to the dissemination of research knowledge by recognising the complexity of educational practice. Additionally, Cooper, Klinger, and McAdie (2017)'s study found that teachers predominantly acquire information (about, for example, assessment practices), from other teachers rather than from research, arguing for the need to use a variety of modes and formats to increase the uptake of research-related products.

On-line access to a vast repository of published material raises the issue of veracity. This is even more crucial in the digital era and with the expansion of social media, for example. Research indicates that teachers regularly fall back on 'tried and tested' materials and methods (Ovenden-Hope and la Velle 2015). The UK government has established The 'What Works Centre for Education' comprised of two long standing educational funding bodies, the Education Endowment Fund (EEF) and the Sutton Trust. The Centre is founded on the principle that 'good decision-making should be informed

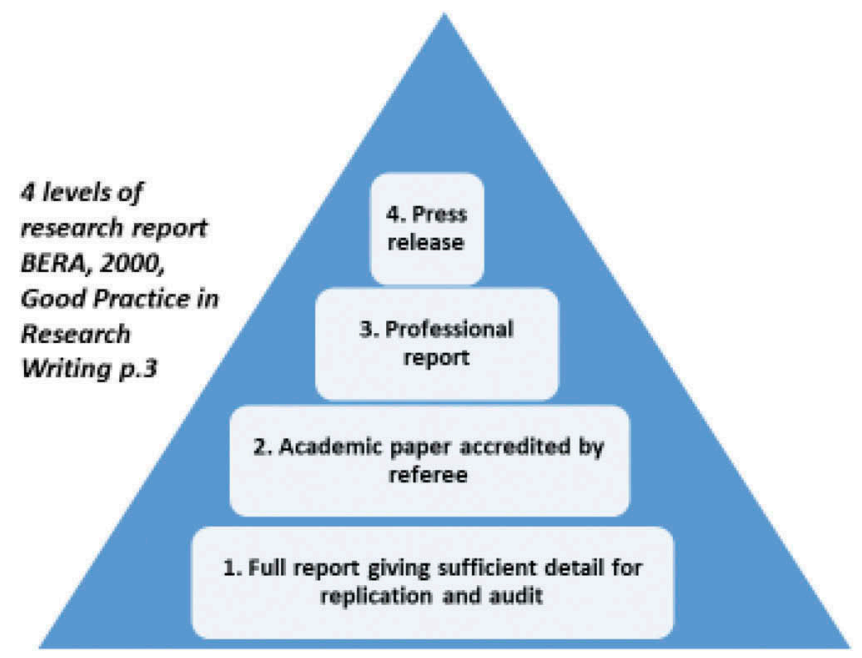

Figure 2. Four levels of publication of research. the audiences for research can progressively be widened. the findings from, for example a $\mathrm{PhD}$ thesis or a research project are written up as a major report to examiners or funders (level 1). From this, papers for journals or book chapters can be derived for an academic audience (level 2). Findings can be made available to the practitioner audience via for example, teachers' publications (level 3). New knowledge can also be published to the general public via a press release (level 4). 
by the best available evidence and if evidence is not available, decision-makers should use high quality methods to find out what works' (Education Endowment Fund 2018). The EEF was established in 2011 with a main aim of narrowing the gap between social disadvantage and educational outcomes. It has a relatively high level of funding from central government ( $£ 125$ million in 2018) and invests much of this in commissioned research. In trying to overcome the problem of scaling up small and often localised research findings, the EFF has funded a series of randomised control trails at a national level, believing this to be a rigorous method of finding out 'what works' in education.

Not surprisingly, this has provoked some controversy in the educational research community. Biesta (2010) argues that the 'what works' idea is based on false assumptions, namely that teaching and learning can adequately be understood as a matter of cause and effect; that the aims of education are given, what matters is the means to achieve these aims; and that what experiments show have worked previously will work in the future. Cain (2016) discusses research utilisation in education, particularly in the UK context, as part of an attempt to replace liberal values with which teaching has been associated with the values of 'what works'. Drawing upon Biesta's work and his view of teaching as a moral and political practice, Cain (2016) unpacks the 'what works' notion and argues that proponents of research utilisation tend to undermine values as the foundation for teachers' decision-making' (p. 618).

Cain (2016) goes on to state, however, that whether research utilisation is a threat to teachers' traditional values is debatable (p. 619). He further argues that

teachers' engagement with research helps them to think critically about their teaching and to improve it, but the route from research findings to implementation is far from linear (p. 625).

In a recent review, Ostinelli (2016) found that if educational research is to have a more significant impact on schools, a number of issues need to be taken into account: pertinence of research, adequate resources, better fit between research and practitioners' needs, orientation to action, more effective interaction between tacit and rational knowledge and presence of consultants/advisors. He argues for the need to move the centre of gravity of educational research from academia to schools and classrooms through extended use of practitioner and action research. Cain (2015) also suggests that

there is little empirical evidence that educational research can inform practice in a direct way, and furthermore, a body of literature which suggests that this is, in principle, impossible (p. 489).

\section{Knowledge mobilisation}

The term 'knowledge mobilisation' refers to the transfer of available knowledge (often from formal research) into active use. Levin (2013) suggests that knowledge mobilisation is based on the

efforts to understand and strengthen the relationship between research and practice". His understanding of the concept reinforces the "interactive, social and gradual nature of the connection between research and practice" which goes beyond a "one-way process (p. 2). 
When defining knowledge mobilisation, Levin (2013) draws attention to the idea of a 'specific effort, over time, working with others, and involves much more than telling people about research findings' (p.2).

According to this author, it involves three overlapping contexts in which knowledge mobilisation occurs: i) production of education research context; ii) the 'use' context (policy or practice setting where research findings are applied); and iii) the mediation context which refers to

all those individuals and organisations who attempt, in one way or another, to connect research to practice, such as think tanks and lobby groups, the media, professional associations, and entrepreneurs (p. 9).

As Jones, Procter, and Younie (2015) suggest, a process of knowledge translation is required to enable research findings to become meaningful for practitioners in their contextual settings. The authors argue for an iterative process as research informs practice, but practice may also inform research. Similarly, and as illustrated in Figure 2 above, Naidorf (2014) highlights the need to distinguish between dissemination and mobilisation, the former being often understood as the communication occurring in academic journals and conferences; the latter making knowledge ready for service or action. She goes on to say that mobilisation implies

more than the mere distribution of research results, it involves one more step in order to mobilise it" (original emphasis). It entails a "complex means of making knowledge more useful, proactive and applied (p. 16).

The distinguishing aim of this mobilisation of knowledge is to improve the outcome for the end user as a result of the practitioner having usefully been informed by research. The affordances of twenty first century information and communication technologies are hugely powerful in mobilising knowledge and the swift transfer of research into practice is now possible on a rapidly expanding scale of volume and convenience. In the medical profession, this knowledge mobilisation, or translational research has been described as research information flowing from 'benchtop to bedside' (Barinaga 1997) and is exemplified through the National Institute for Clinical Excellence (NICE) Guidelines in the UK and the Map of Medicine in the USA. Although there is strong current debate about the relevance of a clinical metaphor for the teaching profession (McLean Davies et al. 2015), the redolent phrase 'from concept to classroom' has variously been coined for an equivalent for the teaching profession, for example in the introduction to the MESH Guides, (Ovenden-Hope, la Velle, and Leask 2014; Jones, Procter, and Younie 2015).

Levin $(2013$, p. 10) suggests that research knowledge mobilisation is

shaped by the way in which the system as a whole is structured, and by the social context in which it takes place". He adds that "the reason that information alone does not change behaviour is because policy and practice are shaped much more by interpersonal relationships and social contexts than by individual knowledge and dispositions (p. 12).

Issues such as communication and dissemination; capacity building, partnerships and networks and systemic approaches are key to knowledge mobilisation strategies, processes and outputs (Nelson and Campbell 2017).

Adding to the debate, Dimmock (2016) argues that 
instead of the traditional knowledge dissemination through one-off workshops, seminars or discussions, knowledge mediation and knowledge application should be in line with the new accounts of professional learning mobilisation (pp. 40-41).

He advocates that the development of knowledge mobilisation is achievable by the concept of a 'research-engaged school'. Qvortrup (2016) also concluded that

in order to change and improve the practice of teachers and principals, a close and interactive relationship between research and practice must be built' namely through problem-based professional learning processes (p. 574).

This author argues for a dynamic and interactive knowledge mobilisation model.

Several attempts have been made to bridge the theory-practice divide by knowledge mobilisation, (e.g. ResearchEd; MESH, EEF, etc.) and there is some evidence of its uptake by practitioners, which although rich in pockets of practice has yet to be widely adopted (Ovenden-Hope and la Velle 2015; Jones, Procter, and Younie 2015).

There is a wide array of ways of fostering knowledge mobilisation. For instance, in initial teacher education and particularly during practicum, as is the case, for example, at the Universities of Minho in Portugal and Melbourne in Australia where notions of knowledge mobilisation and research-informed practice are key underpinning principles which are achieved through action-research projects (Flores and Ferreira 2016; Flores, this volume) or clinical practice (McLean Davies et al. (2015). The aim in both examples is to foster the connection between teaching and research and to develop a more research-based teaching practice.

Knowledge mobilisation in education 'is often reduced to the creation of effective links between academic research and practice in schools and classrooms' (Ostinelli 2016, p. 534). In this regard, there have been several attempts to bridge this gap in order to mobilise evidence-based knowledge for teachers. In the context of on-line communities of practice, Jones, Procter, and Younie (2015) describe the development of the MESH Guides system, which through clickable flow charts provide increasing levels of detail of research information and some interaction, enabling users to apprise themselves of the research background to topics and concepts they may encounter during their day to day practice.

Another response to the provision of digestible amounts of information is the creation of a digital walled garden (Baggott, Nichol, and Ellison 1997) in the form of a curated web crawler. BERTiE (British Educational Research Tool Integrating Engagement), which has been developed as an in-house repository for student teachers on a three year Education course at Bath Spa University, UK (la Velle, Reynolds, and Taylor 2018). BERTiE enables easy access to predefined websites that have been moderated through an academic process. Students benefit from searching education research, policy and comment while being confident that their results have assured academic rigour guaranteed through the curation process. BERTiE's functionality allows the collation and categorisation of broader results including relevant government policy on particular subject areas as well as credible academic blog sites that encourage teachers in the field to engage in scholarly discussion and academic reflection.

The EEF, through the What Works network described above, offers on-line evidence summaries of educational research to guide teachers and educational leaders on how to use resources available to them to maximise learning outcomes. Organised into 'toolkits' 
these summaries claim to offer teachers evidence of what has worked most effectively in the teaching of children from early years through to age 16 years.

Another example of knowledge dissemination and mobilisation may be seen at the Social Publishers Foundation, Inc. (http://www.socialpublishersfoundation.org/kb-browse/ education/), the aim of which is to provide educational activities and funding opportunities for practitioner research and action research projects for improved social welfare and educational practices within communities around the world. Issues such as support, improvement of practice, sharing knowledge, fostering partnerships and knowledge mobilisation are some of its key features. Its rationale is based on the idea that 'When practitioners use research as a tool for strengthening practice, they also produce new knowledge that demonstrates why or how their practice works.' As such, the Foundation provides a 'platform for sharing and for the use of new knowledge, materials, and products generated by practitioner-led research'.

All the initiatives described above to deliver usable research based information to teachers rely on the breadth and reach of the field being effectively covered by the providers of the summaries. Not finding the precise information, possibly using flaky technology, causes immediate frustration to a busy teacher, who will rapidly give up attempts to discover what research is telling him/her about current practice, (OvendenHope and la Velle 2015). Only the most persistent will persevere, but this is likely to be increased if a teacher is enrolled on an accredited course of CPD or a higher degree (Totterdell, Hathaway, and la Velle 2011). In the context of teaching as a research-informed profession, the argument for the provision of impact statements by researchers as well as attempts to publish their work in a variety of ways is therefore reinforced as is that for the universal provision of master's-level teacher education. In this regard, the contrast in teacher education policy between Portugal and the UK is stark: Portugal was quick to implement the Bologna process and teaching there is now a highly qualified profession, with knowledge mobilisation and a required research element being key features of initial teacher education provision, particularly at the University of Minho (see Flores and Ferreira 2016; Flores, this volume). Although there are some exceptions in the UK (for example at the University of Edinburgh), policy churn in England over the past several decades has resulted in a rapidly changing and diverse picture of ITE provision, with no gold, master's level provision (la Velle, 2013; Sorensen 2018), as in Portugal.

\section{Knowledge utilisation}

Research utilisation has been described by Cain (2016) as 'how and why teachers use research findings to understand and improve their practice'. The problem of knowledge utilisation for Dimmock (2016) relates to the hiatus

traced to a well-established institutional division of labour that splits policy-making, research and practice into independent social practices: politicians and bureaucrats make policy, academics research and teachers teach" (p. 39).

Dimmock also stresses that academics are supposed to deal with knowledge production, teachers deal with knowledge transmission and politicians set up 'strategic agendas and directors for both research and teaching' (ibid.). 
He states that 'the resulting institutional hiatus between knowledge production (university-based) and knowledge application (school-based) means that research has limited relevance and impact on practice, to the detriment of both.' (ibid.).

However, as Dimmock and others argue (i.e. Sachs 1999), this is a rather simplistic view as there is also knowledge production in schools through, for instance, action research. This raises the role of teachers as not only consumers of research, but also generators of it. Teachers researching their own practice has been a feature of a number of school-university partnerships focussing on raising the intellectual level of teacher education. In Portugal, Australia and Malta programmes of initial teacher education are offered at the level of a master's degree (Flores 2011; McLean Davies et al. 2015). In the current world wide debate about 'masterliness' of the teaching profession (la Velle 2015) the notion of research informed practice at multiple levels is emphasised.

Initial teacher education (ITE) in Portugal is provided by a 2-year Master's level course for all sectors of teaching (from pre-school to secondary school), which has brought with it not only new challenges but also old problems such as the link between theory and practice and the integration of the curriculum of ITE (see, for instance, Flores 2011, 2014; Flores, Vieira, and Ferreira 2014). The current legal framework (Decree-Law No. 79/2014, 14 May), stipulates five curricular components: subject knowledge, general education, specific didactics, initiation to professional practice, and ethical, social and cultural education. The initiation into professional practice is the component with most credits. It consists mainly of the practicum, which is school-based and supervised by cooperating teachers and university supervisors. It usually takes place in year two of the master's course and includes lesson observation and teaching in the cooperating teachers' classes according to a research stance (see Flores, this volume). Integrating teaching and research is the key element behind the model of practicum, namely at the University of Minho in Portugal. The student teachers are required to do a report of their practicum in which they are expected to mobilise different kinds of knowledge including a research component. Flores and Ferreira (2016) concluded that the new model of practicum, based on research orientation, has been one of the most innovative features of the initial teacher education curriculum after the implementation of the Bologna process. However, they also stress its controversial nature in so far as it has led to tensions and challenges in regard to national visions of teacher education, as well as (mis)matches between curriculum rhetoric and implementation. The same authors also found that critical issues remain such as time spent in schools, the connection between universitybased training and school practice, university-school collaboration in pedagogical inquiry and renewal, and the nature of inquiry. Despite this, Vieira et al. (forthcoming) have argued that the new practicum model is considered to be the major innovation regarding practice-related learning in which a transformative view of teacher development and an inquiry-based approach to teaching are advocated.

Student teachers' use of knowledge brings the theory/practice argument into sharp focus. There are different ways of understanding theory and practice in ITE: clear variations across ITE programmes internationally in terms of the research dimension and its connection (or lack of it) with theory and practice are evident (Flores 2016, 2017). The coherence and integration of various elements of the ITE curriculum, the combination of teaching, research and researching teaching, the role of theory and practice in 
professional learning both in university and school settings are issues that deserve further thinking in developing ITE as a space of transformation (Flores 2016, 2017).

In analysing the concept of partnership in teacher education, through a research mapping, Lillejord and Borte (2016) discuss partnerships as complex and resourceintensive cross-institutional infrastructures for knowledge sharing aiming at enhancing the practice-relevance of teacher education.

\section{A model for research-based enhancement of teachers' knowledge}

As both producers and consumers, teachers' practice has been argued here to be enhanced by engagement with research. We therefore propose a cycle of researchbased teachers' knowledge (see Figure 3) that mirrors the cycle of pedagogic reasoning and action, put forward by Shulman (1987) and described in Figure 1 above. Essentially an upwardly expanding spiral, the knowledge gain cycle in which a teacher acquires new knowledge generated by research, transforms it into a form that will improve practice and through a process of preparation, instruction, evaluation and reflection, gains new understanding as a result of application of the new knowledge brings that teacher to a raised level of pedagogic skill.

This pedagogic enhancement will have a multiplying effect that will contribute to a more research-informed practice, which in turn enhances teacher professionalism. As Sachs (2016) argues, there is a need for systems, schools and teachers to be more research active with teachers' practices validated and supported through research. Enhancing research-based knowledge in teaching entails the consideration of the wide array of variables and contexts such as teachers' knowledge, professional values and dispositions; organisational and cultural aspects of the settings in which they work and the wider social and policy environment. In a recent special issue, Nelson and Campbell (2017), discussing the terminology associated with evidence-informed practice in education, stress that it is not 'simply a technical activity; it is influenced by personal and professional values and beliefs, and affected by wider political and educational contexts, policies, and changes" (p. 128).

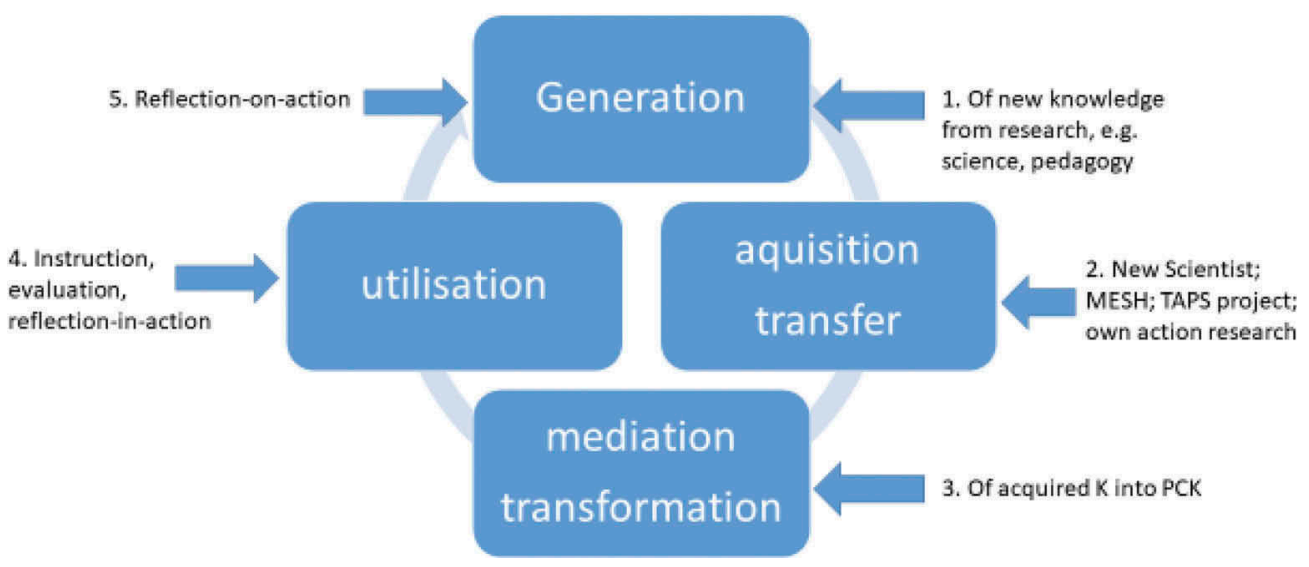

Figure 3. Research-based knowledge enhancement for teaching. 
By accessing relevant presentations of research through such provision as on-line summaries from reliable sources, a teacher acquires new knowledge. A secondary science teacher, for example, may read about a new discovery in genetics to enhance his teaching of biology at the pre-university level; a primary school teacher might learn a new way to assess the skills of her primary school pupils during a practical science enquiry (Earle et al. 2016). Alternatively, knowing exactly what issue a teacher would like to research in their own context, s/he might embark upon an action research project, itself informed by previous research, better to inform practice in that situation. The mediation of the new knowledge involves the transformation, described by Shulman (1987), of substantive or syntactic subject knowledge, such as that of the new genetics discovery, into pedagogic content knowledge (PCK) i.e. that particular professional corpus of teachers' knowledge by which they transform what they know into a form that is learnable by their pupils/students.

Utilising the new knowledge transformed, a teacher undertakes the lesson, using techniques of formative assessment to reflect-in-action (Schön, 1983) on the effectiveness of the instruction. Sometimes referred to as 'in-flight' assessment, this semi-continuous monitoring of pupils' learning informs a teacher of the efficiency of his/her application of the newly generated PCK. More detailed reflection-on-action (ibid) enables a more detailed and systematic deconstruction of the lesson and consideration of how further it might be developed. However, reflection is not an easy task. It involves both content and form in order to be wider, more profound and productive (see, for instance Korthagen 2004; Kelchtermans 2009). Korthagen (2004) draws attention to the importance of reflection by focusing on one's inner potential and on inner obstacles that may be supported by the so-called onion model. This model entails various levels (layers) of reflection ranging from reflection on the

i) environment which refers to the setting the teacher faces, for example, the pupils, the classroom as a whole, and the school culture with its norms;

ii) behaviour, referring to what the teacher does in relation to the environment;

iii) competencies dealing with knowledge and skills, and involving what the teacher is competent at doing;

iv) beliefs, which are related to assumptions or beliefs about the situation and environment, which are often unconscious;

v) identity, referring to teachers' assumptions or beliefs about themselves, their selfconcepts, and the professional roles they see for themselves; and

vi) mission, a layer about what inspires the teacher, what gives meaning and significance to his/her work or life.

Korthagen (2004) also draws attention to core reflection as a key element in developing and improving as a teacher. Reflection is more than an instrumental process that links means and ends. It also deals with the moral, emotional and political issues of teaching as well teachers' beliefs and perceptions of themselves as teachers and their teaching (Kelchtermans 2009).

Reflection is therefore a key element in teaching (Wieser, this volume). Teachers reflect on their action and on their decisions prior, during and after the teaching 
situation: reflection is therefore seen as a crucial part of a teacher's competence (Loughran, Keast, and Cooper 2016). As the authors argue:

Through reflection, it becomes possible to see that the uncertainty of the swampy lowlands of practice require much more than the application of a teaching script or routine to appropriately navigate" (p. 401).

The implications for teacher education are clear. How and when does reflection occur? In which contexts and for which purposes? As the same authors argue, reflection is more than rhetoric and this needs to the understood by pre-service teachers in order for them to 'focus serious attention on the thinking that underpins pedagogical decision-making' (p. 403).

In a similar vein, Rodgers and LaBoskey (2016) state that reflection is more than a technique, it is an orientation and that teacher education and reflective practice is one and the same as it defines the nature of teaching about teaching (p. 72). However, as all experienced teacher educators know, the imperatives of learning to teach, especially during practicum, often mean that time for effective reflection is not made. It is only when appropriate space is made for the exercise of this professional skill that student teachers as well as more experienced classroom teachers can truly benefit in terms of enhancing their practice. In this regard, research has shown that teacher engagement in communities of practice constitutes a foundation for collaboration and reduced isolation, allowing participants to extend teaching and research capacities (Patton and Parker 2017). Issues such as having a common focus, personal and professional relationships, safe but challenging spaces and shared commitment have been identified as key elements in fostering teacher engagement in communities of practice (ibid.).

\section{Conclusions and recommendations for policy and practice}

This paper has elaborated, discussed and illustrated notions of teacher knowledge, its generation, mobilisation and utilisation. We conclude that there is a diverse range of understanding of these notions and that in action, their iterative nature is dependent on an equally wide range of personal, structural, political and social variables. This raises a number of implications for policy-makers, curriculum developers and teacher educators. A crucial consideration is how to create conditions for teachers to exercise their professionalism in ways that are consistent with a view of research embedded in practice. This will require commitment of not only resource, but also implementation of policies that go beyond a narrow view of 'what works' to include collaborative and research-based designs for both CPD and ITE. A deficit model of top-down initiatives and priorities is not helpful in this regard: the teaching profession must be trusted to develop a self-improving system that gives clear social relevance and impact for educational research.

We present a model for Research-Based Teachers' Knowledge that entails a theoretical frame for a means by which teachers' practice can be enhanced. Harnessing knowledge generated by the research community or by practitioners themselves, practice is improved by the multiplying effect of transformation by teachers. The role of the specificity of context in the mediation of knowledge mobilisation is important here, as argued by Levin (2013). Our model is made increasingly powerful by the affordances of the information and communication technologies and although much progress has been made in the last few years to develop a pedagogy of ICT, this lags behind the undeniable ease of access to and 
dissemination of research that is now possible. There is a clear need for more research in this area, especially in contexts where knowledge mobilisation, a central tenet, is a factor. Examples would include practicum in ITE and postgraduate studies where school/university partnerships are a feature.

\section{Disclosure statement}

No potential conflicts of interest were reported by the authors.

\section{References}

Baggott, L., J. D. Nichol, and P. Ellison. 1997. "Educational Informatics for the Biology Teacher." Journal of Biological Education 31 (3): 189-196. doi:10.1080/00219266.1997.9655562.

Barinaga, M. 1997. "From Bench Top to Bedside." Science 278 (5340) :1036-1039. 07 Nov 1997.

Bennett, N., and C. Carré, eds.. 1993. Learning to Teach. London: Routledge.

Ben-Peretz, M., and M. A. Flores. 2018. "Tensions and Paradoxes in Teaching: Implications for Teacher Education." European Journal of Teacher Education 41 (2): 202-213. doi:10.1080/ 02619768.2018.1431216.

Biesta, G.J (2010). "Why 'what works' still won't work: From evidence-based education to valuebased education." Stud Philos Educ. 29:491-503. doi:10.1007/s11217-010-9191-x.

Cain, T. 2015. "Teachers' Engagement with Published Research: Addressing the Knowledge Problem." Curriculum Journal 26 (3): 488-509. doi:10.1080/09585176.2015.1020820.

Cain, T. 2016. "Research Utilization and the Struggle for the Teacher's Soul: A Narrative Review." European Journal of Teacher Education 39 (5): 616-629. doi:10.1080/02619768.2016.1252912.

Cooper, A., D. A. Klinger, and P. McAdie. 2017. "What Do Teachers Need? an Exploration of Evidence-Informed Practice for Classroom Assessment in Ontario." Educational Research 59 (2): 190-208. doi:10.1080/00131881.2017.1310392.

Council for the Accreditation of Educator Preparation (CAEP, 2018). aepnet.org/standards/k-6elementary-teacher-standards (accessed 18:07:2001).

Decree-Law (2014) Decree-Law number79/2014, $14^{\text {th }}$ May, available at https://dre.pt/web/guest/ pesquisa/-/search/25344769/details/maximized

Dimmock, C. 2016. "Conceptualising the Research-Practice-Professional Development Nexus: Mobilising Schools as 'Research Engaged' Professional Development Learning Communities." Professional Development in Education 42 (1): 36-53. doi:10.1080/19415257.2014.963884.

Duggan, M., and L. la Velle. 2018. "Embracing Complexity: Understanding the Experiences of University Based Teacher Educators." edited by N. Sorensen. Diversity in Teacher Education in England: a study of a school-led system. Pub Trentham (in press).

Duncan, B.J. (1998). "Response: On Teacher Knowledge: a return to Shulman." In Philosophy of Education 1998. edited by Tozer, S.E. Urbana,IL: Philosophy of Education Society.

Earle, S., K. McMahon, C. Collier, and A. Howe (2016) The Teacher Assessment in Primary Science (TAPS School Self-Evaluation Tool. Downloadable At https://pstt.org.uk/application/files/8414/ 5761/9871/Intro_to_TAPS_sch_self_eval_pyramid_Jan_2016.pdf (accessed 18:07:2003)

Flores, M. A. 2011. "Curriculum of Initial Teacher Education in Portugal: New Contexts, Old Problems." Journal of Education for Teaching 37 (4): 461-470. doi:10.1080/02607476.2011.611015.

Flores, M. A., F. Vieira, and F. I. Ferreira. 2014. "Initial Teacher Training in Portugal: Problems, Challenges and the Place of Practice in Master's Degrees in post-Bologna Teaching." In Initial Teacher Training: National and International Perspectives and Perspectives, edited by M. C. Borges and O. F. Aquino, 61-96. Uberlândia: EDUFU. 978-85-7078-373-1.

Flores, M. A. 2014. "Teacher Learning in the Workplace in Pre-Service Teacher Education in Portugal: Potential and Limits from a Pre-Service Teacher Perspective." In Workplace Learning in Teacher Education. International Practice and Policy, edited by O. McNamara, J. Murray, and M. Jones, 243-260. Dordrecht: Springer. 
Flores, M. A. 2016. International Handbook of Teacher Education, Eds. T. E. Curriculum, J. Loughran, and M. L. Hamilton., 187-230. Dordrecht: Springer Press.

Flores, M. A., and M. S. Richmond. 2017. "Cultivating Hope through Teacher Leadership in Portugal." In Empowering Teachers as Agents of Change: A Non-Positional Approach to Teacher Leadership, edited by D. Frost, 125-130. Cambridge: University of Cambridge Press.

Flores, M. A. 2017. "Editorial. Practice, Theory and Research in Initial Teacher Education." European Journal of Teacher Education 40: 287-290. n³. doi:10.1080/02619768.2017.1331518.

Flores, M. A., and F. I. Ferreira. 2016. "Education and Child Poverty in Times of Austerity in Portugal: Implications for Teachers and Teacher Education." Journal of Education for Teaching 42 (4): 404416. doi:10.1080/02607476.2016.1215549.

Fund, E. E. (2018) https://educationendowmentfoundation.org.uk/about/what-works-network/ accessed 18:07:2003.

Government, U. K. (2011). https://www.gov.uk/government/publications/teachers-standards (accessed 19:07:2001)

Henderson, J. 1988. "A Curriculum Response to the Knowledge Base Reform Movement." Journal of Teacher Education 39 (5): 13-17. doi:10.1177/002248718803900504.

Hill, H. C., D. Loewenberg Ball, and S. G. Schilling. 2008. "Unpacking Pedagogical Content Knowledge: Conceptualizing and Measuring Teachers' Topic-Specific Knowledge of Students." Journal for Research in Mathematics Education 39 (4) :372-400. Jul., 2008.

Jones, S. L., R. Procter, and S. Younie. 2015. "Participatory Knowledge Mobilisation: An Emerging Model for International Translational Research in Education." Journal of Education for Teaching,41, no. 5: 555-573. doi:10.1080/02607476.2015.1105540.

Kelchtermans, G. 2009. "Professional Commitment beyond the Contract: Self-Understanding, Vulnerability and Reflection of the Teachers." In Teacher Learning and Professional Development: Contexts and Perspectives, edited by M. A. Flores and A. M. Veiga Simão, 61-98. Mangualde: Edições Pedago.

Ketter, J., and B. Stoffel. 2008. "Getting Real: Exploring the Perceived Disconnect between Education Theory and Practice in Teacher Education." Studying Teacher Education 4 (2): 129142. doi:10.1080/17425960802433611.

Korthagen, F. 2004. "In Search of the Essence of a Good Teacher: Towards a More Holistic Approach in Teacher Education." Teaching and Teacher Education 20: 77-97. doi:10.1016/j.tate.2003.10.002.

La Velle, L. M., K. Watson, and J. D. Nichol. 2000. "Otherscope - the Virtual Reality Microscope - Can the Real Learning Experiences in Practical Science Be Simulated?." Int J Health Technology Management 2 (5/6): 539-556. 2000. 1386-2156. doi:10.1504/IJHTM.2000.001098.

Levin, B. 2013. "To Know Is Not Enough: Research Knowledge and Its Use." Review of Education 1 (1): 2-31. doi:10.1002/rev3.3001.

Lillejord, S., and K. Borte. 2016. "Partnership in Teacher Education - A Research Mapping." European Journal of Teacher Education 39 (5): 550-563. doi:10.1080/02619768.2016.1252911.

la Velle, L.M. (2013). "ICT,teaching and learning: what do the latest mobile technologies afford?." Journal of Biological Education 47(2):71-72.

la Velle, L. M. 2015. Masterliness in the Teaching Profession. Pub: Routledge: Abingdon Oxford, UK. ISBN13 978-1-138-81363-2.

la Velle, L. M., K. Reynolds, and S. Taylor. 2018. BERTiE: Early Evaluation of a Digital Innovation for EvidenceBased Engagement in Initial Teacher Education Association for Teacher Education Europe Winter Meeting, Hogeschool, Utrecht, Netherlands. Book of Abstracts, p41. (TEDT-29. 15-16 February, 2018. ATEE. Available at https://husite.nl/atee/download-full-paper/ (accessed 29-08-18).

Loughran, J., S. Keast, and R. Cooper. 2016. "Pedagogical Reasoning in Teacher Education." In International Handbook of Teacher Education, edited by J. Loughran and M. L. Hamilton, 387421. Vol. 1. Singapore: Springer.

McLean Davies, L., B. Dickson, F. Rickards, S. Dinham, J. Conroy, and R. Davis. 2015. "Teaching as a Clinical Profession: Translational Practices in Initial Teacher Education - An International Perspective." Journal of Education for Teaching 41 (5): 514-528. Translational Research and Knowledge Mobilisation in Teacher Education. doi:10.1080/02607476.2015.1105537. 
Milburn, C. (2005) Education Research 'irrelevant' https://www.theage.com.au/news/national/edu cation-research-irrelevant/2005/07/01/1119724808289.html (accessed18:07:2010)

Naidorf, J. 2014. "Knowledge Utility: From Social Relevance to Knowledge Mobilization." Education Policy Analysis Archives 22 (89): 1-31.

Nelson, J., and C. Campbell. 2017. "Evidence-Informed Practice in Education: Meanings and Applications." Educational Research 59 (2): 127-135. doi:10.1080/00131881.2017.1314115.

Oolbekkink-Marchand, H. W., L. L. Hadar, K. Smith, and I. Helleve. 2017. "Teachers' Perceived Professional Space and Their Agency." Teaching and Teacher Education 62: 37-46. doi:10.1016/j. tate.2016.11.005.

Ostinelli, G. 2016. “The Many Forms of Research-Informed Practice: A Framework for Mapping Diversity." European Journal of Teacher Education 39 (5): 534-549. doi:10.1080/02619768.2016.1252913.

Ovenden-Hope, T., L. La Velle, and M. Leask (2014) Using 'MESH Guides' as Translational Research and Knowledge Mobilisation for Continuing Professional Development in Schools. CICE-2014 Proceedings: Canada International Conference on Education, pp 497-498. Pub: Infonomics Society, 978-1-908320-24-7.

Ovenden-Hope, T., and L. M. La Velle. 2015. "Translational Research in Education for Knowledge Mobilisation: A Study of Use and Teacher Perception in Primary Schools in England, UK." Journal of Education for Teaching 41 (5) 574-585. doi:10.1080/02607476.2015.1105541.

Patton, K., and M. Parker. 2017. "Teacher Education Communities of Practice: More than a Culture of Collaboration." Teaching and Teacher Education 67: 351-360. doi:10.1016/j.tate.2017.06.013.

Pine, G. J. 2013. "The Disconnection between Educational Research and Practice: The Case for Teacher Action Research" G. J. Pine edited by.Teacher Action Research: Building Knowledge Democracies. 9781412964760. Sage Publications.

Qvortrup, L. 2016. “Capacity Building: Data and Research-Informed Development of Schools and Teaching Practices in Denmark and Norway." European Journal of Teacher Education 39 (5): 564576. doi:10.1080/02619768.2016.1253675.

Rey, O., and M. Gaussel. 2016. "The Conditions for the Successful Use of Research Results by Teachers: Reflections on Some Innovations in France." European Journal of Teacher Education 39 (5): 557-587. doi:10.1080/02619768.2016.1260117.

Rodgers, C., and V. K. LaBoskey. 2016. "Reflective Practice." In International Handbook of Teacher Education, edited by J. Loughran and M. L. Hamilton, 71-104. Vol. 2. Singapore: Springer.

Sachs, J. 1999. "Using Teacher Research as a Basis for Professional Renewal." Journal of In-Service Education 25 (1): 39-53. doi:10.1080/13674589900200072.

Sachs, J. 2016. "Teacher Professionalism: Why are We Still Talking about It?" Teachers and Teaching Theory and Practice 22 (4): 413-425. doi:10.1080/13540602.2015.1082732.

Schön, D. 1983. The Reflective Practitioner: How Professionals Think in Action. London: Temple Smith.

Shulman, L. S. 1987. "Knowledge and Teaching: Foundations of the New Reforms." Harvard Educational Review 57 (1): 1-22. doi:10.17763/haer.57.1.j463w79r56455411.

Smeyers, P. 2006. "The Relevance of Irrelevant Research; the Irrelevance of Relevant Research." In Educational Research: Why 'What Works' Doesn't Work, edited by P. Smeyers and M. Depaepe. Dordrecht: Springer.

Sockett, H. 1987. "Has Shulman Got the Strategy Right?." Harvard Educational Review 57 (2): 208219. doi:10.17763/haer.57.2.n026767181833w77.

Sorensen, N., Ed. 2018. Diversity in Teacher Education in England: Teacher Supply within a School-Led System. Staffordshire: Trentham Books Ltd.

Totterdell, M., T. Hathaway, and L. La Velle. 2011. "Mastering Teaching and Learning through Pedagogic Partnership: A Vision and Framework for Practice-Based Learning in Support of Teacher Professional Development." In Professional Development in Education 37 (3) 411-437. Taylor and Francis.

Vieira, F., M. A. Flores, J. L. Silva, and J. Almeida. forthcoming. "Understanding and Enhancing Change in post-Bologna Pre-Service Teacher Education: Lessons from Experience and Research in Portugal." In Leading Change in Teacher Education: Lessons from Education Leaders around the Globe, edited by T. Al-Barwani, M. A. Flores, and D. Imig. London: Routledge.

Zeichner, K. 2014. "The Struggle for the Soul of Teaching and Teacher Education in the USA." Journal of Education for Teaching 40 (5): 551-568. 